\title{
Analysis of Investment Decisions in Sharia Cooperatives: Does Sharia Accounting Standards Affect?
}

\author{
Abd. Kholik Khoerulloh \\ Inspektorat Kabupaten Majalengka, Indonesia \\ email: akhok29@gmail.com \\ Yadi Janwari \\ Universitas Islam Negeri Sunan Gunung Djati Bandung, Indonesia \\ email: yadijanwari@uinsgd.ac.id
}

\begin{abstract}
Investors in sharia cooperatives in Majalengka Regency suffered losses due to its administrators and managers who were not transparent in reporting their finances. This research aims to determine the effect of the application of sharia accounting standards and human resource competencies on investment decisions through financial reporting quality. The analytical techniques used in this study use path analysis. The results showed that the application of Sharia accounting standards had no significant adverse effect on investment decisions through financial reporting quality with an original sample value of -0.021 and $\mathrm{P}_{\text {value }} 0.554>0.05$. In contrast, human resource competence significantly affected investment decisions through financial reporting quality with original sample values of 0.403 and $\mathrm{P}_{\text {value }}$ of $0.044<0.05$. The implication of this research is to improve sharia cooperative management in financial performance to attract members to invest. The novelty of this research is the motive of investing in sharia cooperatives.
\end{abstract}

Keywords: Accounting; Competence; Financial Report; Investment Decisions

\begin{abstract}
Abstrak: Investor pada koperasi syariah di Kabupaten Majalengka mengalami kerugian karena ulah para pengurus dan pengelolanya yang tidak transparan dalam melaporkan keuangannya. Penelitian ini bertujuan untuk mengetahui pengaruh penerapan standar akuntansi syariah dan kompetensi sumber daya manusia terhadap keputusan investasi melalui kualitas laporan keuangan. Teknikanalisis yang digunakan dalam penelitian ini menggunakan analisis jalur. Hasilnya menunjukkan bahwa penerapan standar akuntansi syariah berpengaruh negatif tidak signifikan terhadap keputusan investasi melalui kualitas laporan keuangan dengan nilai original sample sebesar - 0.021 dan $\mathrm{P}_{\text {value }}$ $0.554>0.05$, sedangkan kompetensi sumber daya manusia berpengaruh positif signifikan terhadap keputusan investasi melalui kualitas laporan keuangan dengan nilai original sample sebesar 0.403 dan $\mathrm{P}_{\text {value }} 0.044<0.05$. Implikasi dari penelitian ini adalah meningkatkan manajemen koperasi syariah dalam kinerja keuangan sehingga menarik anggota untuk berinvestasi. Kebaruan dari penelitian ini adalah motif investasi pada koperasi syariah.
\end{abstract}

Kata Kunci: Akuntansi; Kompetensi; Laporan Keuangan; Keputusan Investasi

Economica: Jurnal Ekonomi Islam - Volume 12, Nomor 1 (2021) 
Abd. Kholik Khoerulloh and Yadi Janwari

\section{Introduction}

The development of sharia cooperatives in Indonesia is significant; this is due to the high public awareness of the importance of practicing Islamic values in economic activities. As with Majalengka Regency, the development of sharia cooperatives has increased; its existence can touch the middle and lower economic communities. People can borrow business capital easily and in a way that does not violate sharia. Sharia cooperatives are the answer to the demands and needs of Muslims. Besides, sharia cooperatives are also used as investment places for people who have excess assets.

Investment is one of the recommended activities in Islam. The Prophet SAW has carried out investment activities (Pardiansyah 2017), and investment has many benefits for individuals and the wider community. One will get a return by investing, and the other will benefit from additional venture capital (Archer and Karim 2012). For some Majalengka people, sharia cooperatives are the most appropriate entity to invest. One of the advantages of investing in sharia cooperatives is the withdrawal of investments that can be made flexibly.

However, based on data found in the Majalengka Regency Cooperative and SME Office (Majalengka 2017) and the results of research field surveys, until in 2017, there were three problematic sharia cooperatives, namely BMT al-Amanah, KBMT Sri Mukti, and BMT Babussalam. As a result, Sharia cooperatives cannot return their members' deposits, which reached approximately 10 billion. Furthermore, but sharia cooperatives also cannot pay off their debts to LPDB (Revolving Fund Management Institution). This happens because there is much fraud committed by the managers and managers of sharia cooperatives. The managers and managers are not transparent in reporting their finances, meaning they report fraudulently and do not follow reality (Pratikno 2018). This incident affected other sharia 
cooperative members in Majalengka Regency in deciding to invest or save (Luthfi 2018).

Several factors can influence investment decision-making, including applying accounting standards, human resource competency, and financial reporting quality. Based on the Regulation of the Minister of Cooperatives and SMEs of the Republic of Indonesia number 14/Kep/M.KUKM/IX/2015, sharia cooperatives are required to apply accounting standards that apply based on sharia principles. The implementation of accounting standards can improve financial reporting quality to influence investment decision-making. The application of accounting standards in financial statements can improve the quality of fair value accounting. To ensure a high level of transparency (Palea 2013). By applying these accounting standards, sharia cooperatives apply the principles of transparency, openness, and accountability so that they can be recognized, trusted, and accepted by their members or the wider community. So that in practice, sharia cooperatives should be able to apply accounting information properly and properly (Ikhsan and Haridhi 2017). The more accounting standards are applied, the higher the investment value (Gao and Sidhu 2018).

The competence of human resources available to an entity is one factor in investment decision-making. Human resource competency affects financial reporting quality (Putri, Maryono, and Bagana 2017), and financial reporting quality affects the level of investment (Houcine 2017). Good human resource management will result in an excellent organization to reduce cheating in economics and finance. Then with healthy financial conditions, it will undoubtedly attract the attention of investors (Petraşcu, Bucur, and Dobre 2015).

Besides, another factor that can influence investment decision-making is financial reporting quality. Financial reporting quality affects investment decisions to reduce investment yield uncertainty (Ferracuti and Stubben 2019). Other research suggests that financial reporting quality can improve 
investment decisions because it reduces the mismanagement of financial information between managers and investors (Roychowdhury, Shroff, and Verdi 2019). Good accounting information will increase the attractiveness of its users to invest or invest (Hairston and Brooks 2019).

Based on the above description, the researchers are interested in researching sharia accounting standards, human resource competencies, the quality of financial reports, and their influence on investment decisions on sharia cooperatives in the Majalengka Regency.

\section{Literature review}

\section{Sharia cooperatives}

The cooperative is a business entity consisting of a person or legal entity of the cooperative by under ruling its activities based on the cooperative's principles and a people's economic movement based on the principle of kinship (Republik Indonesia 1992). Sharia cooperatives are nongovernmental organizations as economic institutions that seek to develop productive businesses and investments based on sharia principles (Rusydiana and Devi 2018).

Based on the above understanding, sharia cooperatives are cooperative legal entities that conduct their business based on the Quran and al-Hadith. Sharia cooperatives in Indonesia usually use various terms, such as KBMT (Koperasi Baitul Maal wa Tamwil), KJKS (Koperasi Jasa Keuangan Syariah) and KSPPS (Koperasi Simpan Pinjam Pembiayaan Syariah). Because of cooperatives law, sharia cooperatives are small and medium-sized financial entities under the Ministry of Cooperatives and SMEs of the Republic of Indonesia. However, some people there are often mistakes in distinguishing between KJKS or sharia cooperatives and LKMS. 


\section{Sharia accounting standards}

Sharia accounting standards are accounting standards used by entities that conduct their business based on sharia principles. The sharia accounting standard stipulated in this study is PSAK Syariah, Indonesia's prevailing sharia accounting standard developed by IAI. PSAK Syariah was developed to record accounting that adheres to Islamic principles. Previous literature has shown that sharia accounting standards are necessary to distinguish between conventional and sharia transactions (Laux and Stocken 2018). In addition, other literature states that sharia accounting standards were developed to answer the problems IAI faces. Namely the absence of international accounting standards such as the International Financial Reporting Standard (IFRS) or the Statement of Financial Accounting Standards (PSAK) (Archer and Karim 2012).

\section{Human resource competencies}

According to Watson Wyatt, competency is a combination of skill, knowledge, and attitude that can be observed critically for an organization's success, work performance, and employee contributions to its company (Ruky 2013). Human resources are the human power unit of a company organization and not just the summation of existing employees. Some human resources unions must be seen as one continuous system between one employee and another and serve to achieve the vision and mission of the organization (Matindas 2002). Human resource competencies are the characteristics and abilities of a person in the form of skills, knowledge, and attitudes necessary in carrying out their duties in the place of employment. To know the expected level of performance that goes into the category of good or average takes a level of competency. Determining the competency threshold needed can be used as the selection process, succession planning, human resource development, and performance evaluation (Siahaya, Asnawi, and Layuk 2018).

Economica: Jurnal Ekonomi Islam - Volume 12, Nomor 1 (2021) 
Based on the description, it concluded that the competence of human resources is an integral part of the skills, knowledge, and attitudes of a person. This section is needed to carry out their duties as employees of a company organization or work environment. It can also be used as the basis for planning, developing, and evaluating company performance. Therefore, human resource competency that becomes a research variable is all elements of competency owned by the administrators and managers of sharia cooperatives in the Majalengka Regency.

\section{Financial reporting quality}

Financial reporting quality presents all relevant and reliable information about the entity's business. Therefore, a good level of disclosure and presentation of the entity itself is required (Sari and Suaryana 2014). Qualitative characteristics of financial statements are normative measures that need to be realized in accounting information to meet the objectives (Nordiawan 2010). The quality standards of cooperative financial statements must meet the criteria: reliable, understandable, relevant, complete, appeal, test power, and on time (Sudarwanto 2013). The description concluded that financial reporting quality is good, wrong financial statements presented by an entity. The more reliable, relevant, complete, and understandable a financial statement is presented, the more qualified the financial statements presented.

\section{Investment decisions}

Investment is a commitment to several funds or other resources made at this time to make future profits (Tandelilin 2010). Thus, investment delays current consumption for ineffective and efficient production processes over time (Jogiyanto 2013). At the same time, an investment decision is an individual's decision to keep some of his funds on a particular type of investment (Sofi Ariani et al. 2015). Thus, the authors conclude that 
investment decisions can be defined as an individual's decision to invest a particular type of investment to make a profit in the future.

The source of funds for investment can come from current assets such as investing a certain amount of funds in real assets (land, machinery, buildings) as well as financial assets (stock deposits or bonds), loans from third parties, or savings (Bahri 2017). In the scope of sharia cooperatives, four types of investments are often used: special deposits, principal deposits, mandatory deposits, and voluntary deposits (Ridwan 2013). In this study, the discussion of investment decisions is an investment decision made by members of sharia cooperatives who have deposits or investments.

Some sharia agreements are used in investment transactions. Both invest in the real and non-real sectors, public and private companies, government and private companies (Pardiansyah 2017). First, Musyarakah Contract is a cooperation agreement between two or more parties by including capital either in money or other assets to conduct business. Second, a Mudharabah contract is a business cooperation agreement between two or more parties where one party as shahibul maal (owner of capital) and one party as mudharib (capital manager). The system implemented in this contract is shahibul maal handing over its capital to mudharib, then the capital is managed by mudharib. The agreed ratio will distribute the profits earned from this business.

Third, Ijarah contract is a contract made between service provider or leaser (mu'jir) and tenant or service user (musta'jir) to give benefits to the object of ijarah that can be the benefit of goods or services within a particular time, with payment of wages or rent payment (ujrah) without being followed by the transfer of ownership of the object of the ijarah. Fourth, the Kafalah contract is a contract made by the guarantor (kafil) and the insanity party or the person in debt (makful 'anhu) to guarantee the liability of the guaranteed party to makful lahu (the other party or the party that has receivables). Fifth, Wakalah contract is made by the authorized party (muwakkil) with the 
representative (the receiving party). Muwakkil (authority) authorizes the representative to perform a particular act or action.

\section{Methods}

\section{Types and data sources}

The type used in this study is descriptive research with a quantitative approach. Descriptive research is carried out to provide an overview or description of the research variables (Sudjarweni 2015). At the same time, the quantitative approach is carried out with statistical methods to test the hypothesis proposed (Sugiyono 2015a). The type of data in this study is quantitative data; it is data in numbers then processed, tested, and analyzed using statistics (Sekaran 2006). The quantitative data obtained in this study concerns indicators of sharia accounting standards, human resource competencies, financial reporting quality, and investment decisions which are then transformed into figures. We get the data from the respondent through the questionnaire that he has filled out.

\section{Population and samples}

The population in this study is all members who invest in cooperative legal entities located in Majalengka Regency by considering things like 1) cooperatives conducting their business based on sharia, 2) supervised by the Sharia Supervisory Board, and 3) conducting annual Member Meeting (RAT) for three consecutive years. Thus included in the population of this study are members who invest in sharia cooperatives with characteristics that have been determined by the authors, namely: KJKS BMT Talaga, KJKS an-Nur, KSPPS IPHI, KSPPS Karya Insani, and KBMT Jabal Rahmah. 
The population in the study was 56 members. Then taken into the sample using the Slovin technique (Riduwan 2015), then the result is as follows:

$$
\begin{aligned}
& \mathrm{n}=\frac{\mathrm{N}}{1+\left(\mathrm{Nxe}^{2}\right)} \\
& \mathrm{n}=\frac{56}{1+\left(56 \times 0,05^{2}\right)} \\
& \mathrm{n}=\frac{56}{1+0,14} \\
& \mathrm{n}=\frac{56}{1,14} \\
& \mathrm{n}=49,12 ; \text { rounded into } 50
\end{aligned}
$$

Description:

$$
\begin{aligned}
& \mathrm{n}=\text { sample size } \\
& \mathrm{N}=\text { population } \\
& \mathrm{e}=\text { error standard }
\end{aligned}
$$

\section{Data analysis techniques}

The data analysis techniques in this study aim to compile and interpret the data that has been obtained (Priyono 2008). There are several data analysis techniques used in this study, namely: 1) reliability test, this test is used to measure a questionnaire or questionnaire which is an indicator of a variable or construct (Sunyoto 2016); 2) multicollinearity test, conducted to determine whether there is a correlation relationship between independent variables in the regression model (Khoeruloh et al. 2020) (Sugiyono 2013); 3) regression test, this test is used to predict how far dependent variable values change if independent variable values are manipulated or changed or up and down (Sugiyono 2015); and 4) Hypothesis test, this test is used to determine 
Abd. Kholik Khoerulloh and Yadi Janwari

the significance of the influence of independent variables, dependent variables, and intervening variables.

\section{Research Model}

Based on the background and theories forward above, the research model used in the writing of this article is as figure 1 . Based on the research model in figure 1, there are several hypotheses that researchers want to ask, namely as follows:

$\mathrm{H}_{1}$ :Sharia accounting standards affect financial reporting quality.

$\mathrm{H}_{2:}$ Human resource competencies affect financial reporting quality.

$\mathrm{H}_{3}$ : Sharia accounting standards affect investment decisions.

$\mathrm{H}_{4:}$ Human resource competencies affect investment decisions.

$\mathrm{H}_{5:}$ Financial reporting quality affects investment decisions.

$\mathrm{H}_{6:}$ Sharia accounting standards affect investment decisions through financial reporting quality.

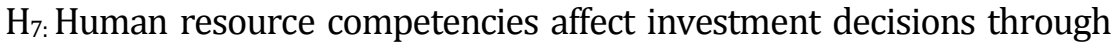
financial reporting quality.

Figure 1. Research Models

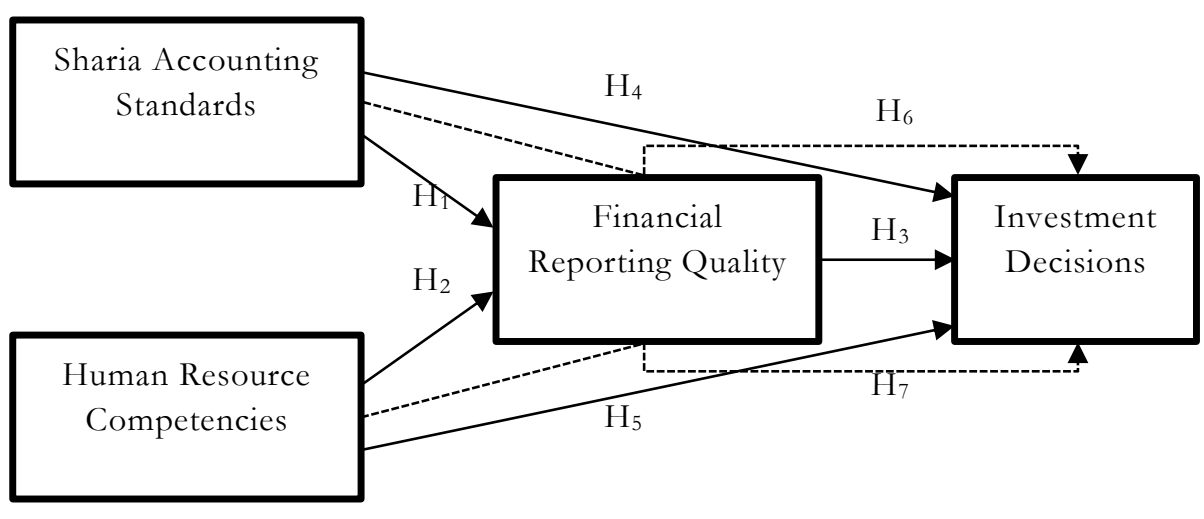


Table 1. Reliability test results

\begin{tabular}{lccc}
\hline Variabel & $\begin{array}{c}\text { Cronbach's } \\
\text { Alpha }\end{array}$ & rkritis & $\begin{array}{c}\text { N of } \\
\text { Items }\end{array}$ \\
\hline Sharia Accounting Standard & 0.745 & 0.6 & 13 \\
Human Resource Competencies & 0.820 & 0.6 & 13 \\
Financial Reporting Quality & 0.916 & 0.6 & 13 \\
Investment Decisions & 0.858 & 0.6 & 13 \\
\hline
\end{tabular}

Source: primary processed data (2020)

\section{Result and discussion}

\section{Reliability test}

The reliability test aims to know the extent of the consistency of the respondents in answering the given question. The more consistent the respondent's answer, the more reliable the question asked (Sunyoto 2016). The reliability test results on each variable are as shown in table 1 .

A construct is reliable if it provides Cronbach's alpha value is $>0.6$ (Ghozali 2012). Based on the table above, it can be noted that each variable has a value of Cronbach's alpha $>0.6$. That shows that all variables in this study are reliable.

\section{Multicollinearity Test}

To determine whether multicollinearity in the regression model can be seen from the tolerance value or variance inflation factor (VIF) value (Santoso 2010). If the tolerance value is low, then the variance inflation factor (VIF) value will be high because of VIF $=1 /$ tolerance. Therefore, the tolerance value limit is 0.10 , while the variance inflation factor (VIF) value limit is 10 . That is, if the tolerance value is 0.10 and the variance inflation factor (VIF) value is < 10 , then there is no multicollinearity in independent variables (Gujarati 2012). For more details, here are the results of multicollinearity testing in this study. 
Abd. Kholik Khoerulloh and Yadi Janwari

Table 2. Multicollinearity test results

\begin{tabular}{lcc}
\hline Variable & \multicolumn{2}{c}{ Collinearity Statistics } \\
\cline { 2 - 3 } & Toleranca & VIF \\
\hline Sharia Accounting Standard & 0.828 & 1.213 \\
Human Resource Competencies & 0.394 & 2.536 \\
Financial Reporting Quality & 0.449 & 2.229 \\
\hline
\end{tabular}

Dependent Variable: Investment Decisions

Source: primary processed data (2020)

Table 2 showed that the tolerance value on the standard variable sharia accounting is $0.828>0.10$, and the value of VIF is $1.213<10$. So it can be concluded that there is no multicollinearity on the standard variables of sharia accounting. The tolerance value on the human resource competency variable is $0.394>0.10$ and the VIF value is $2.536<10$. So it can be concluded that there is no multicollinearity on human resource competency variables. The tolerance value on variable quality financial statements is $0.449>0.10$ and the VIF value is $2.229<10$. So it can be concluded that there is no multicollinearity on variable quality financial statements.

\section{Hypothesis test}

Before testing the hypothesis, determine in advance the level of significance; the level significance in this study is $\alpha=0.05$. then look for the value of $\mathrm{P}_{\text {value }}$ and compared it to the value of $\alpha$. If the value $\alpha>\mathrm{P}_{\text {value, then Ho }}$ is rejected, concluding that independent variables significantly affect dependent variables (Sugiyono, 2015a). Furthermore, it can be seen from the original sample value to find out the direction of positive or negative relationships between independent and dependent variables. If the original sample value is positive, then the direction of the relationship between the independent variable and the dependent variable is positive, and vice versa. 
The hypothesis test in this research uses path analysis. Path analysis can take into account direct influences and indirect influences (Juanim 2004). Path analysis determines the indirect influence of independent variables on dependent variables through intervening variables tested using the Sobel test (Kline 2011). A Sobel test is used to determine the effect of significance given intervening variables with the following equations (Ghozali 2013).

$$
\mathrm{T}=\frac{\mathrm{ab}}{\sqrt{\mathrm{b}^{2} \mathrm{SE}_{\mathrm{a}}^{2}+\mathrm{a}^{2} \mathrm{SE}_{\mathrm{b}}^{2}}}
$$

$\mathrm{T}=\mathrm{T}_{\text {statistics }}$ that indicates the standard value of the $\mathrm{T}$ distribution

$\mathrm{a}=$ regression coefficient of independent variables against intervening variables

$\mathrm{b}=$ regression coefficient of intervening variables against dependent variables

$\mathrm{SE}_{\mathrm{a}}=$ standard error of estimation from the effect of independent variables on intervening variables

$\mathrm{SE}_{\mathrm{b}}=$ standard error of estimation from the effect of intervening variables on dependent variables

\section{Direct effect test (path coefficients bootstrapping technique)}

Based on the hypothesis that has been submitted, a direct effect test is carried out on the hypothesis: 1) the effect of sharia accounting standards on financial reporting quality; 2) the effect of human resource competency on financial reporting quality; 3) the effect of sharia accounting standards on investment decisions; 4) the effect of human resource competency on investment decisions; 5) the effect of financial reporting quality on investment decisions. 
Abd. Kholik Khoerulloh and Yadi Janwari

Table 3. Direct effect test results

\begin{tabular}{lcccccc}
\hline Path Coefficient & $\begin{array}{c}\text { Original } \\
\text { Sample }\end{array}$ & $\begin{array}{c}\text { Simple } \\
\text { Mean }\end{array}$ & $\begin{array}{c}\text { Standard } \\
\text { Deviation }\end{array}$ & $\begin{array}{c}\text { T } \\
\text { Statistics }\end{array}$ & T Table & $\begin{array}{c}\text { P } \\
\text { Value }\end{array}$ \\
\hline $\begin{array}{l}\text { Sharia Accounting } \\
\text { Standard } \rightarrow \text { Financial }\end{array}$ & -0.055 & -0.096 & 0.099 & 0.557 & 2.01063 & 0.578 \\
$\begin{array}{l}\text { Reporting Quality } \\
\begin{array}{l}\text { Human Resource } \\
\text { Competencies } \rightarrow\end{array}\end{array}$ & 1.055 & 0.961 & 0.115 & 6.814 & 2.01063 & 0.000 \\
$\begin{array}{l}\text { Financial Reporting } \\
\text { Quality }\end{array}$ & & & & & & \\
$\begin{array}{l}\text { Sharia Accounting } \\
\text { Standard } \rightarrow \text { Investment } \\
\text { Decisions }\end{array}$ & 0.022 & -0.067 & 0.146 & 0.149 & 2.01063 & 0.881 \\
$\begin{array}{l}\text { Human Resource } \\
\text { Competencies } \rightarrow\end{array}$ & 0.596 & 0.537 & 0.223 & 2.675 & 2.01063 & 0.008 \\
$\begin{array}{l}\text { Investment Decisions } \\
\text { Financial Reporting } \\
\text { Quality } \rightarrow \text { Investment } \\
\text { Decisions }\end{array}$ & 0.382 & 0.335 & 0.188 & 2.029 & 2.01063 & 0.043 \\
\hline
\end{tabular}

Source: primary processed data (2020)

Table 3 showed that the relationship between sharia accounting standards and financial reporting quality is insignificant, with a $\mathrm{P}_{\text {value }}$ of 0.578 $>0.05$ and a $\mathrm{T}_{\text {statistics }}$ value of 0.557 . The original sample value is negative at 0.055 , which indicates that the relationship between sharia accounting standards and financial reporting quality is negative. Thus, $\mathrm{H} 1$ in this study states that Sharia accounting standards affect financial reporting quality rejected.

The relationship between human resource competence and financial reporting quality is significant with $\mathrm{P}_{\text {value }} 0,000<0.05$ and $\mathrm{T}_{\text {statistics }}$ of 6,814 . Furthermore, the original sample value was positive at 1,055 , indicating that the relationship between human resource competence and financial reporting quality is positive. Thus, $\mathrm{H} 2$ in this study states that human resource competencies affect financial reporting quality accepted.

The relationship between sharia accounting standards and investment decisions is insignificant with $\mathrm{P}_{\text {value }} 0.881>0.05$ and $\mathrm{T}_{\text {statistics }}$ of 0.149 . However, the original sample value is a positive 0.022 , which indicates that the direction 
of the relationship between sharia accounting standards and investment decisions is positive. Thus, H3 in this study states that Sharia accounting standards affect investment decisions rejected.

The relationship between human resource competence and investment decisions is significant with $\mathrm{P}_{\text {value }} 0.008<0.05$ and $\mathrm{T}_{\text {statistics }} 2,675$. The original sample value was a positive 0.596 , which indicates that the direction of human resource competency relationship with investment decisions is positive. Thus, H4 in this study states that human resource competence affects investment decisions accepted.

The relationship between financial reporting quality and investment decisions is significant with $\mathrm{P}_{\text {value }} 0.043<0.05$ and $\mathrm{T}_{\text {statistics }} 2.029$. Furthermore, the original sample value was a positive 0.382 , which indicates that the direction of the related financial reporting quality with investment decisions is positive. Thus, $\mathrm{H} 5$ in this study states that financial reporting quality affects investment decisions accepted.

\section{Indirect effect test (path coefficients bootstrapping technique)}

Based on the hypothesis, the indirect influence test is carried out on the hypothesis: 1) the effect of sharia accounting standards on investment decisions through financial reporting quality; 2) the effect of human resource competencies on investment decisions through financial reporting quality.

Tabel 4. Indirect effect test results

\begin{tabular}{lcccccc}
\hline \multicolumn{1}{c}{ Path Coefficient } & $\begin{array}{c}\text { Original } \\
\text { Sample }\end{array}$ & $\begin{array}{c}\text { Simple } \\
\text { Mean }\end{array}$ & $\begin{array}{c}\text { Standard } \\
\text { Deviation }\end{array}$ & $\begin{array}{c}\text { T } \\
\text { Statistics }\end{array}$ & T Table & $\begin{array}{c}\text { P } \\
\text { Value }\end{array}$ \\
\hline $\begin{array}{l}\text { Sharia Accounting } \\
\text { Standard } \rightarrow \text { Financial } \\
\text { Reporting Quality } \rightarrow\end{array}$ & -0.021 & -0.026 & 0.035 & 0.035 & 2.01063 & 0.554 \\
$\begin{array}{l}\text { Investment Decisions } \\
\text { Human Resource }\end{array}$ & 0.403 & 0.327 & 0.199 & 2.022 & 2.01063 & 0.044 \\
$\begin{array}{l}\text { Competencies } \rightarrow \\
\text { Financial Reporting } \\
\text { Quality } \rightarrow \text { Investment } \\
\text { Decisions }\end{array}$ & & & & & & \\
\hline
\end{tabular}

Source: Primary processed data (2020)

Economica: Jurnal Ekonomi Islam - Volume 12, Nomor 1 (2021) 
Abd. Kholik Khoerulloh and Yadi Janwari

Table 4 showed that The relationship between sharia accounting standards and investment decisions through financial reporting quality is insignificant with $\mathrm{P}_{\text {value }} 0.554>0.05$ and $\mathrm{T}_{\text {statistics }}$ 0.035. Furthermore, the original sample value is negative at -0.021 , which indicates that the direction of sharia accounting standard relationship with investment decisions through financial reporting quality is negative. Thus, $\mathrm{H} 6$ in this study stating that sharia accounting standards affect investment decisions through financial reporting quality rejected.

The relationship between human resource competence and investment decisions through financial reporting quality is significant with $\mathrm{P}_{\text {value }}$ of 0.044 $<0.05$ and $\mathrm{T}_{\text {statistics }} 2,022$. Furthermore, the original sample value was a positive 0.403, indicating that the direction of human resource competency relationship with investment decisions through financial reporting quality is positive. Thus, H7 in this study states that human resource competencies affect investment decisions through financial reporting quality accepted.

In summary, based on the results of hypothesis testing, the following is a research model as shown in figure 2.

Figure 2. Hypothetical test results in research models

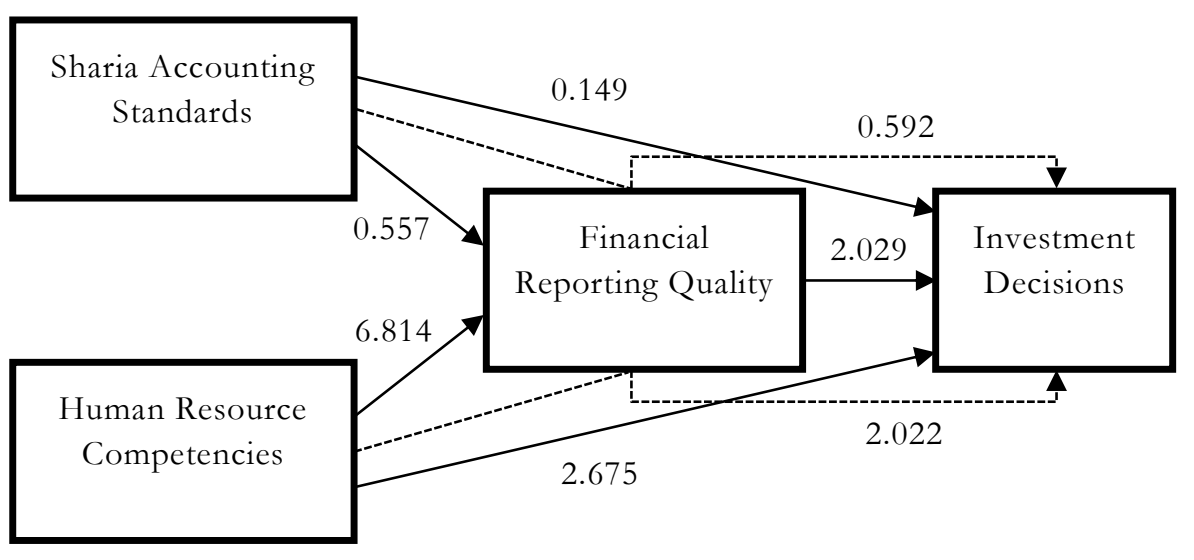




\section{Discussion}

Based on the hypothesis tests, we can know that the quality of financial statements has a significant positive effect on investment decisions. These results support research that has been conducted by Asma Houcinel and Mohamed Chakib Kolsi (2017) in their research. This shows that the members who invest consider the quality of sharia cooperative financial statements in Majalengka Regency; they see the financial position statement and income statement that will be used as a reference for members in making investment decisions. In addition, prospective investors (prospective members of cooperatives) can see how the management and financial performance of cooperatives and financial statements are also used as a basis for predicting the reciprocity of investments and consideration materials.

Sharia financial accounting standards have an insignificant negative effect on investment decisions through financial reporting quality. These results are not in line with research conducted by Vera Palea (2013) in her research entitled IAS/IFRS and financial reporting quality: Lessons from the European experience. Palea said that implementing International Accounting Standards or International Financial Report Standards (IAS/IFRS) could improve financial reporting quality to influence investment decisions. So it can be said that the application of accounting standards affects investment decisions through the quality of the report, in contrast to this study, which states that Islamic accounting standards have an insignificant negative effect on investment decisions through the quality of financial reporting. This is because the samples used in Vera Palea's research are those in Europe, where they always involve applying accounting standards in investment decisionmaking. At the same time, the samples in this study are people who can be considered villagers who do not understand accounting standards.

Human resource competencies have a significant positive effect on investment decisions through financial reporting quality. Daniela Petraşcu, Mihai Adrian Bucur, and Elena Dobre (2015) In her research entitled: 
Analyzing the Management of Human Resource in Economic-Financial Fraud Investigation. The researchers say that setting up human resources well can attract investors. This result is following the research that is being conducted that states that human resource competency affects investment decisions. The better the competence of human resources, the better the level of investment in sharia cooperatives. The members who invest consider the human resource competencies of sharia cooperatives in Majalengka Regency; they see the honesty and security of the administrators and managers in maintaining the mandate in the form of money or investment capital held by members. Therefore, if sharia cooperatives want a very high investment value, then honesty and security are required from the administrators and managers.

\section{Conclusion}

Many frauds are committed by the managers and managers of sharia cooperatives in Majalengka. This is because the managers and managers are not transparent in reporting their finances, meaning they report their finances fraudulently and not following the reality. This incident affects other sharia cooperative members in Majalengka Regency in making decisions to invest or save. This study showed that the application of sharia accounting standards had an insignificant negative effect on investment decisions through financial reporting quality with a $\mathrm{P}_{\text {value }}$ of $0.554>0.05, \mathrm{~T}_{\text {statistics }} 0.035$, and original samples of -0.021 . On the other hand, human resource competence significantly affects investment decisions through financial reporting quality with $\mathrm{P}_{\text {value }}$ of $0.044<0.05, \mathrm{~T}_{\text {statistics }} 2,022$, and an original sample of 0.403 .

Investors, who in this case are cooperative members of sharia cooperatives in Majalengka Regency, do not consider the application of sharia accounting standards in investment decision making. However, they consider the competence of human resources in investment decision-making. They see how the attitudes and ethics of the administrators and managers of sharia cooperatives. 
Furthermore, the following are some recommendations that will be put forward, including 1) sharia cooperative administrators and managers are expected to continue to improve themselves by attending seminars or training organized by the government or other institutions; 2) sharia cooperative supervisors are expected to continue to monitor the performance of administrators and managers as a form of internal supervision, this is aimed at minimizing unexpected fraud; 3 ) the government is expected to conduct training aimed at improving human resource competencies in sharia cooperatives; 4) the government is expected to improve its function as an external supervisor of sharia cooperatives through the office that houses the cooperative, and 5) researchers are further expected to conduct more extensive coverage studies to make a more significant contribution as well.

\section{References}

Archer, Simon, and Rifaat Ahmed Abdel Karim. 2012. "Measuring Risk for Capital Adequacy: The Issue of Profit-Sharing Investment Accounts." In Islamic Finance, 223-36. 2 Clementi Loop, \#02-01, Singapore 129809: John Wiley \& Sons (Asia) Pte Ltd. https://doi.org/10.1002/9781118390443.ch10.

Bahri, Syaiful. 2017. "Pengaruh Free Cash Flow, Laba Bersih, Dan Ukuran Perusahaan Terhadap Keputusan Investasi." Jurnal Penelitian Teori \& $\begin{array}{lllll}\text { Terapan } & \text { Akuntansi (PETA) } & 2 & \text { (1): }\end{array}$ https://doi.org/10.51289/peta.v2i1.200.

Ferracuti, Elia, and Stephen R. Stubben. 2019. "The Role of Financial Reporting in Resolving Uncertainty about Corporate Investment Opportunities." Journal of Accounting and Economics 68 (2-3): 101248. https://doi.org/10.1016/j.jacceco.2019.101248.

Gao, Ru, and Baljit K. Sidhu. 2018. "The Impact of Mandatory International Financial Reporting Standards Adoption on Investment Efficiency: Standards, Enforcement, and Reporting Incentives." Abacus 54 (3): 277318. https://doi.org/10.1111/abac.12127. 
Abd. Kholik Khoerulloh and Yadi Janwari

Ghozali, Imam. 2012. Aplikasi Analisis Multivariate Dengan Program IBM SPSS. Yogyakarta: Universitas Diponegoro.

———. 2013. Aplikasi Analisis Multivariate Dengan Program IBM SPSS 21 Update PLS Regresi. Semarang: Badan Penerbit Universitas Diponegoro.

Gujarati. 2012. Dasar-Dasar Ekonometrika. 5th ed. Jakarta: Salemba Empat.

Hairston, Stephanie A., and Marcus R. Brooks. 2019. "Derivative Accounting and Financial Reporting Quality: A Review of the Literature." Advances in Accounting 44 (October): 81-94. https://doi.org/10.1016/j.adiac.2018.10.003.

Houcine, Asma. 2017. "The Effect of Financial Reporting Quality on Corporate Investment Efficiency: Evidence from the Tunisian Stock Market." Research in International Business and Finance 42 (December): 321-37. https://doi.org/10.1016/j.ribaf.2017.07.066.

Ikhsan, Amrul, and Musfiari Haridhi. 2017. "Penerapan Standar Skuntansi Keuangan Syariah Pada Koperasi Jasa Keuangan Syariah (Studi Pada Baitul Qiradh Di Kota Banda Aceh)." Jurnal Ilmiah Mahasiswa Ekonomi Akuntansi Unsyiah 2 (3): 100-110.

Jogiyanto, Hartono. 2013. Teori Portofolio Dan Analisis Investasi. Yogyakarta: BPFE.

Juanim. 2004. Analisis Jalur Dalam Riset Pemasaran Teknik Pengolahan Data SPSS \& LISREL. Bandung: Fakultas Ekonomi Universitas Pasundan Bandung.

Khoeruloh, Abd Kholik, Gita Priyanti, Neng Sri Astuti Sya'adah, and Anggi Amirudin. 2020. "Inflasi Dan BI 7-Day Repo Rate: Faktor Penentu Profitabilitas Bank Umum Syariah Di Indonesia." Maro: Jurnal Ekonomi $\begin{array}{lllll}\text { Syariah Dan } & \text { Bisnis } & 3 & \text { (1): }\end{array}$ https://doi.org/10.31949/mr.v3i1.2097.

Kline, R. B. 2011. Principles and Practice Equation Modeling. New York: Guilford Press.

Laux, Volker, and Phillip C. Stocken. 2018. "Accounting Standards, Regulatory Enforcement, and Innovation." Journal of Accounting and Economics 65 (2-3): 221-36. https://doi.org/10.1016/j.jacceco.2017.11.001.

Luthfi, Adi. 2018. Berinvestasi pada Koperasi Syariah.

Economica: Jurnal Ekonomi Islam - Volume 12, Nomor 1 (2021) https://journal.walisongo.ac.id/index.php/economica 
Majalengka, Dinas Koperasi dan UKM Kabupaten. 2017. "Data Umum Kopeerasi Di Kabupaten Majalengka." Majalengka.

Matindas, R. 2002. Manajemen Sumber Daya Manusia: Lewat Konsep AKU (Ambisi, Kenyataan Dan Usaha). Jakarta: Pustaka Utama Grafiti.

Nordiawan, Deddi. 2010. Akuntansi Sektor Publik. Jakarta: Salemba Empat.

Palea, Vera. 2013. "IAS/IFRS and Financial Reporting Quality: Lessons from the European Experience." China Journal of Accounting Research 6 (4): 247-63. https://doi.org/10.1016/j.cjar.2013.08.003.

Pardiansyah, Elif. 2017. "Investasi Dalam Perspektif Ekonomi Islam: Pendekatan Teoritis Dan Empiris." Economica: Jurnal Ekonomi Islam 8 (2): 337-73. https://doi.org/10.21580/economica.2017.8.2.1920.

Petraşcu, Daniela, Mihai Adrian Bucur, and Elena Dobre. 2015. "Analysing the Management of Human Resource in Economic-Financial Fraud Investigation." Procedia Economics and Finance 27 (15): 209-15. https://doi.org/10.1016/S2212-5671(15)00992-2.

Pratikno, Indra. 2018. Kasus Koperasi Syariah di Majalengka.

Priyono. 2008. Metode Penelitian Kuantitatif. Surabaya: Zifatama Publishing.

Putri, Mega Andani, Maryono Maryono, and Batara Daniel Bagana. 2017. "Kompetensi Sumber Daya Manusia, Penerapan Sistem Akuntansi Keuangan Daerah, Penerapan Standar Akuntansi Pemerintahan, Dan Pengendalian Intern Terhadap Kualitas Laporan Keuangan Daerah Pada Satuan Kerja Perangkat Daerah Kota Semarang." Jurnal Dinamika Akuntansi, Keuangan Dan Perbankan 6 (2): 153-63.

Republik Indonesia. 1992. Undang-Undang Republik Indonesia Nomor 25 Tahun 1992 Tentang. Indonesia.

Riduwan. 2015. Dasar-Dasar Statistika. Bandung: Alfabeta.

Ridwan, Ahmad Hasan. 2013. Manajemen Baitul Mal Wa Tamwil. Bandung: Pustaka Setia.

Roychowdhury, Sugata, Nemit Shroff, and Rodrigo S. Verdi. 2019. "The Effects of Financial Reporting and Disclosure on Corporate Investment: A Review." Journal of Accounting and Economics 68 (2-3): 101246. https://doi.org/10.1016/j.jacceco.2019.101246.

Ruky, Achmad S. 2013. Sistem Manajemen Kinerja. Jakarta: Gramedia Pustaka Utama.

Economica: Jurnal Ekonomi Islam - Volume 12, Nomor 1 (2021) 
Rusydiana, Aam Slamet, and Abrista Devi. 2018. “Mengembangkan Koperasi Syariah Di Indonesia: Pendekatan Interpretative Structural Modelling (ISM)." Economica: Jurnal Ekonomi Islam 9 (1): 1-23. https://doi.org/10.21580/economica.2018.9.1.2181.

Santoso, Singgih. 2010. Statistik Multivariat. Jakarta: PT Elex Media Komputindo.

Sari, Luh Indah Novita, and I G. N. Agung Suaryana. 2014. "Pengaruh Kualitas Laporan Keuangan Pada Efisiensi Investasi Perusahaan Pertambangan." E- Joural Akuntansi Universitas Udayana 8 (3): 524-37.

Sekaran, Uma. 2006. Metodologi Penelitian Untuk Bisnis. Semarang: Badan Penerbit Universitas Diponegoro.

Siahaya, Erwin, Meinarni Asnawi, and Paulus K. Allo Layuk. 2018. "Pengaruh Kompetensi Sumber Daya Manusia, Sistem Pengendalian Intern Pemerintah Dan Penerapan Sistem Akuntansi Keuangan Daerah Terhadap Kualitas Laporan Keuangan Pemerintah Provinsi Papua." Keuda: Jurnal Kajian Ekonomi Dan Keuangan Daerah 3 (1): 1-16. https://doi.org/10.31957/keuda.v3i1.714.

Sofi Ariani, Putri Asiza Agustien Aulia Rahmah, Yurisha Ramadhani Putri, Maulidatur Rohmah, Antika Budiningrum, and Lutfi. 2015. "Pengaruh Literasi Keuangan, Locus of Control, Dan Etnis Terhadap Pengambilan Keputusan Investasi." Journal of Business and Banking 5 (2): 257-70. https://doi.org/10.14414/jbb.v5i2.550.

Sudarwanto, Adenk. 2013. Akutansi Koperasi: Pendekatan Praktis Penyusunan Laporan Keuangan. Yogyakarta: Graha Ilmu.

Sudjarweni, V. Wiratna. 2015. Metodologi Penelitian Bisnis Dan Ekonomi. Yogyakarta: Pustaka Baru Press.

Sugiyono. 2013. Metode Penelitian Kuantitatif, Kualitatif Dan R\&D. Bandung: Alfabeta.

___. 2015a. Metode Penelitian Manajemen. Bandung: Alfabeta.

_-_. 2015b. Statistika Untuk Penelitian. 26th ed. Bandung: Alfabeta.

Sunyoto, Danang. 2016. Metodologi Penelitian Akuntansi. Bandung: Reflika Adimata.

Tandelilin, Eduardus. 2010. Portofolio Dan Investasi: Teori Dan Aplikasi. Yogyakarta: Kanisius. 